Название: Functional Coatings of Ternary Alloys of Cobalt with Refractory Metals

Другие названия: Функциональные покрытия тройными сплавами кобальта с тугоплавкими металлами

Авторы: N. D. Sakhnenko, M. V. Ved, Yu. K. Hapon, T. A. Nenastina

Сахненко Николай Дмитриевич sakhnenko@kpi.kharkov.ua

Ведь Марина Витальевна

Гапон Юлия Константиновна

Ненастина Татьяна Александровна

Ключевые слова: cobalt-molybdenum-tungsten coatings

citrate-pyrophosphate electrolyte

corrosion resistance

surface morphology

pulsed electrolysis

покрытия кобальт-молибден-вольфрам

цитратно-пирофоссратный электролит

коррозионная стойкость

морфология поверхности

импульсный электролиз

Дата публикации: 2015

Издатель: Springer, Heidelberg, Allemagne

Библиографическое

Functional Coatings of Ternary Alloys of Cobalt with

описание: Refractory Metals / N. D. Sakhnenko [et al.] // Russian

Journal of Applied Chemistry. - 2015. - Vol. 88. No 12. - pp. 1941-1945.

DOI 10.1134/S1070427215012006X

Peфpepaт: Finely crystalline cobalt-molybdenum-tungsten coatings were deposited in the nonsteady-state mode from a polyligand citrate-pyrophosphate electrolyte at a concentration ratio of the alloy-forming components $\mathrm{Co}^{2+} /$ $\left(\mathrm{WO}_{4}{ }^{2-}+\mathrm{MoO}_{4}{ }^{2-}\right)=1: 1$ and citrate/pyrophosphate ligands of $1: 2$. It was found that the quantitative composition and current efficiency by the ternary alloy depends on the current density. The effect of energy- and time-related parameters of the pulsed electrolysis on the surface morphology and roughness was studied. It was shown that, as the total content of refractory metals in Co-Mo-W coatings increases, the corrosion rate decreases in the acid medium and increases in the alkaline medium because of the instability of molybdenum and tungsten oxides.

Из полилигандного цитратно-пирофоссратного электролита при соотношении концентраций сплавообразующих компонентов $\mathrm{Co}^{2+} /\left(\mathrm{WO}_{4}{ }^{2-}+\mathrm{MoO}_{4}{ }^{2-}\right)=$ $1: 1$, и лигандов цитрат / пирофросфрат $=1: 2$ в нестационарном режиме получены мелкокристаллические покрытия кобальт-молибденвольфрам. Установлена зависимость количественного состава и выхода по току тройного сплава от плотности 
тока. Исследовано влияние энергетических и временных параметров импульсного электролиза на морфологию и шероховатость поверхности. Показано, что при увеличении суммарного содержания тугоплавких металлов в покрытиях Co-Mo-W скорость коррозии в кислой среде снижается, а в щелочной увеличивается изза неустойчивости оксидов молибдена и вольфрама.

Location: http://link.springer.com/article/10.1134/S1070427215012006X 


\title{
Functional Coatings of Ternary Alloys of Cobalt with Refractory Metals
}

\author{
N. D. Sakhnenko ${ }^{a}$, M. V. Ved ${ }^{a}$, Yu. K. Hapon ${ }^{a}$, and T. A. Nenastina ${ }^{b}$ \\ ${ }^{a}$ National Technical Unhersity Kharkiv Polytechnic Institute, Bagaliya vul. 21, Kharkiv, 61000 Ukraine \\ ${ }^{b}$ Kharkiv National Automobile and Highway University, Yaroslava Mudrogo vul., Kharkiv, 61002 Ukraine \\ e-mail: yuliano4ka@inbox.ru
}

Received November 27, 2015

\begin{abstract}
Finely crystalline cobalt-molybdenum-tungsten coatings were deposited in the nonsteady-state mode from a polyligand citrate-pyrophosphate electrolyte at a concentration ratio of the alloy-forming components $\mathrm{Co}^{2+} /$ $\left(\mathrm{WO}_{4}^{2-}+\mathrm{MoO}_{4}^{2-}\right)=1: 1$ and citrate/pyrophosphate ligands of $1: 2$. It was found that the quantitative composition and current efficiency by the ternary alloy depends on the current density. The effect of energy- and time-related parameters of the pulsed electrolysis on the surface morphology and roughness was studied. It was shown that, as the total content of refractory metals in Co-Mo-W coatings increases, the corrosion rate decreases in the acid medium and increases in the alkaline medium because of the instability of molybdenum and tungsten oxides.
\end{abstract}

DOI: $10.1134 / \mathrm{S} 1070427215012006 \mathrm{X}$

Particular attention is given in modem industrial manufacture to development and implementation of new progressive technologies. A particular place is occupied among the most demanded materials by cobalt alloys, whose spectrum of functional properties is broadened by alloying with refractory metals and, in particular, tungsten and molybdenum. Introduction of refractory metals into coatings makes it possible to obtain corrosion-resistant, catalytic, magnetic, and highstrength materials [1] with a wide variety of application areas.

Depending on the component ratio, the properties of alloys of this kind may strongly vary: alloys with high content of cobalt exhibit magnetic properties and can be used in devices for information recording and storage; alloys with high content of molybdenum and tungsten have a high hardness, chemical and corrosion resistance, alloys of this kind can be used to improve the wear resistance of machine parts operating in corrosive media at high temperatures.

These alloys are commonly obtained by alloying or condensation of the necessary components, which are either energy-intensive or require use of high-precision equipment, whereas the galvanochemical technologies foe their deposition are devoid of these shortcomings and create the minimum technogenic load on the environment [2-5].

Individual coating with tungsten and molybdenum cannot be deposited from aqueous solutions; however, their codeposition into an alloy with iron-subgroup metals $(\mathrm{Fe}, \mathrm{Co}, \mathrm{Ni})$ is well known [6,7]. Alloys of cobalt with tungsten and molybdenum are more frequently deposited from electrolytes based on citrate, chloridecitrate, pyrophosphate, and pyrophosphate-citrate complexes, and introduction of sodium ethylenediaminetetraacetate (EDTA) into an electrolytic bath favors an increase in the content of refractory components in the alloy [8]. However, it follows from an analysis of scientific-technological and patent sources that the information about binary alloys is prevalent, whereas that about electrolytic formation of temary alloys of cobalt with molybdenum and tungsten is hardly available, although a synergic effect would be expected for these alloys. Development of theoretical foundations for obtaining 
electrolytic alloys of this kind, optimization of the electrolyte compositions and electrolysis parameters, and study of the functional properties of coatings with ternary alloys are of indubitable interest, and just this circumstance predetermined the goal of the present study.

\section{EXPERIMENTAL}

The cobalt-molybdenum-tungsten alloy was electrodeposited from a polyligand citrate-pyrophosphate electrolyte with unipolar pulsed current with amplitude of 4-27.5 $\mathrm{A} \mathrm{dm}^{-2}$ at frequencies in the range $f=19$ $910 \mathrm{~Hz}$. The pulse width was varied within the range $\tau_{\text {pulse }}=2 \times 10^{-3}-2 \times 10^{-1} \mathrm{~s}$, and that of the pause, $\tau_{\text {pause }}=$ $2 \times 10^{-1} \mathrm{~s}$, with the duty factor $q=\left(\tau_{\text {pulse }}+\tau_{\text {pausc }}\right) / \tau_{\text {pulse }}$ being $2-20$. The electrodeposition modes were set with a PI-50-1.1 potentiostat with a PR-8 programming unit. The potentiostat was equipped with a board for automated on-line data recording with a program specially developed for digitization of the measurement results. Parallel cobalt plates served as soluble anodes. The electrolyte $\mathrm{pH}$ was set to $8-10$ by introduction of potassium hydroxide and monitored and adjusted in the course of experiments. The alloy coatings were deposited at temperatures of 293 to $343 \mathrm{~K}$.

Solutions were prepared from analytically pure reagents: $\mathrm{CoSO}_{4} \cdot 7 \mathrm{H}_{2} \mathrm{O}, \mathrm{Na}_{2} \mathrm{MoO}_{4} \cdot 2 \mathrm{H}_{2} \mathrm{O}, \mathrm{Na}_{2} \mathrm{WO}_{4} \cdot 2 \mathrm{H}_{2} \mathrm{O}$, $\mathrm{Na}_{3} \mathrm{C}_{6} \mathrm{H}_{5} \mathrm{O}_{7} \cdot 3 \mathrm{H}_{2} \mathrm{O}$, and $\mathrm{K}_{4} \mathrm{P}_{2} \mathrm{O}_{7}$. The reagents were dissolved in small amounts of distilled water, after which the solutions were mixed in a certain order with consideration for the complexation processes in the electrolyte bulk $[9,10]$.

The alloy coatings were deposited onto copper and St.3 steel substrates. The sample surface was prepared by the commonly accepted procedure, depending on the nature of a material.

The current efficiency (CE) by the alloys was determined gravimetrically on the assumption that metals are incorporated into the coatings in the fully reduced state. The theoretical gain in mass as a result of the electrodeposition was calculated by the Faraday law, the electrochemical equivalent of an alloy, $k_{\mathrm{e}}$, was found by the formula

$$
\frac{1}{k_{\mathrm{e}}}=\sum \frac{\omega_{i}}{k_{i}},
$$

where $\omega_{i}$ is the content of ith component in the alloy (wt \%), and $k_{i}$ is the electrochemical equivalent of $i$ th component of the alloy $\left(\mathrm{kg} \mathrm{C}^{-1}\right)$.

The practical gain in mass was used to calculate the thickness of the alloy coating obtained, for which purpose the density of the alloy was determined:

$$
\frac{1}{\rho}=\sum \frac{\omega_{i}}{\rho_{i}},
$$

where $\rho_{i}$ is the density of the $i$ th component of the alloy $\left(\mathrm{kg} \mathrm{m}^{-3}\right)$.

The chemical composition of the coatings was determined by the X-ray fluorescence method with a $S_{\text {prut }}$ portative spectrometer, and the phase composition, with a DRON-3M X-ray diffractometer $\left(\mathrm{Cu} K_{\alpha}\right.$ radiation, $\lambda=1.5405 \AA$ ). The elemental composition and the surface morphology of the coatings were analyzed by scanning electron microscopy (SEM) with a Zeiss EVO 40XVP microscope. Images were obtained by recording secondary electrons via scanning with an electron beam, which made it possible to examine the topography with high resolution and contrast. The error in measuring the content of the components was $\pm 1 \mathrm{wt} \%$.

The surface roughness was determined with an NT206 atomic-force probe microscope. The scanning areas were chosen in the upper, middle, and lower parts of a sample at a distance of $1500 \mu \mathrm{m}$ from each other. The scanning was performed by the contact method with a CSC-37 probe and B cantilever with a lateral resolving capacity of $3 \mathrm{~nm}$. The identity of the surface characteristics at different parts of a sample was observed for all the structures, which enabled extrapolation of the data to the characteristics of a whole sample.

The corrosion resistance of the materials was evaluated on the basis of gravimetric and polarization measurements. The corrosion current density jcor was determined by extrapolation at the intersection point of linear portions of the partial anodic and cathodic polarization dependences plotted in the Tafel coordinates $\log i-\Delta E$ at a corrosion potential $E_{\mathrm{cor}}$

The known values of the corrosion current were used to calculate the depth corrosion index $k_{\mathrm{h}}$ by the equation

$$
k_{\mathrm{h}}=\frac{8.76 k_{\mathrm{e}} j_{\mathrm{cor}}}{\rho},
$$

where $j_{\text {cor }}$ is the corrosion current density $\left(\mathrm{A} \mathrm{m}^{-2}\right)$. 